\title{
Chemical and Biological Investigation of Organic Wastes of Frying Oils and Beef Fats: Valorization for Biodiesel Production
}

\author{
Yasmine Souissi, ${ }^{1,2}$ Meha Alouini, ${ }^{1,3}$ and Wissem Mnif $\mathbb{I D}^{1}$ \\ ${ }^{1}$ BVBGR-LR11ES31, Institut Supérieur de Biotechnologie de Sidi Thabet (ISBST), Université de la Manouba, 2020 Ariana, Tunisia \\ ${ }^{2}$ Higher Institute of Environment Sciences and Technologies of Borj Cedria, University of Carthage, Tunis, Tunisia \\ ${ }^{3}$ Département Génie Biologique, Université Libre de Tunis, 32 Bis Av. Kheireddine Pacha, 1002 Tunis, Tunisia \\ Correspondence should be addressed to Wissem Mnif; w_mnif@yahoo.fr
}

Received 26 August 2017; Revised 31 October 2017; Accepted 18 December 2017; Published 22 January 2018

Academic Editor: Francisco Javier Deive

Copyright (C) 2018 Yasmine Souissi et al. This is an open access article distributed under the Creative Commons Attribution License, which permits unrestricted use, distribution, and reproduction in any medium, provided the original work is properly cited.

\begin{abstract}
The present study investigates the different approaches of biodiesel production by exploiting low cost feedstocks such as organic wastes of frying oils (WFO) and wastes of beef fats (WBF). The aim was to compare not only two different sources of waste raw materials but also different approaches of biodiesel production. Biodiesel which refers to fatty acid methyl esters (FAME) was produced by both chemical and enzymatic transesterification. The characterization of the biodiesel produced by both approaches was performed according to the European standard EN 14214. The results showed that the biological method gave a richer FAME biodiesel through the catalysis of whole-cell lipase. However, for the chemical method, better biodiesel physicochemical properties were observed for the two raw materials. Therefore, it would be interesting to compromise by optimizing the biological biodiesel production approach in order to obtain a better quality in coherence with EN 14214 requirements.
\end{abstract}

\section{Introduction}

The rapid depletion of fossil fuel reserves has made biodiesel an attractive alternative fuel in recent times due to its similar characteristics to diesel fossil fuel. Moreover, biodiesel is eco-friendly fuel since it produces exhaust gas of sulfur and aromatic compound and is biodegradable and nontoxic [1]. Biodiesel essentially consists of a mixture of fatty acid methyl esters as defined by the American Society for Testing and Materials (ASTM) derived from renewable feedstocks $[2,3]$. Fatty and organic wastes such as waste frying oil (WFO) and waste beef fat (WBF) are considered as potential alternative feedstocks for biodiesel production [4-6]. These materials will have double environmental benefits by reducing their environmental pollution and producing an eco-friendly fuel [7]. Indeed, the amounts of WFO generated by homes and restaurants are increasing rapidly $[3,8]$. WFO spilled in the sink often leads to contamination of recipient waters [9]. The amount of WBF rejected from slaughterhouses is also important based on an assessment on deposit of organic wastes in Tunisia conducted by the National Agency of Waste
Management. The amount reached $48 \cdot 10^{3}$ ton in 2009 in Tunisia [10]. Both WFO and WBF cause serious problems in water treatment plant $[5,9]$. Therefore, the strategy is to convert these sources into commercial grade biodiesel which was reported by several French and European texts and in particular the article $n^{\circ} 29$ of the law $2005 n^{\circ} 781$ [11]. However, the direct use of these wastes is impractical because of the high viscosity and free fatty acid content $[12,13]$. The most common process to reduce viscosity and to improve the physical properties of biodiesel is transesterification $[12,13]$. The transesterification refers to a chemical reaction involving triglycerides with alcohol (methanol) to yield methyl esters (biodiesel) and glycerol as a by-product [14-16]. This reaction can be carried out by different catalytic processes [17]. Figure 1 shows the transesterification reaction.

Most attention on biodiesel production has focused on alkali catalyzed transesterification. However, this process has several drawbacks. Indeed, the downstream processing steps of the product obtained as the recovery of glycerol, removing inorganic salts and water, are complex [18-20]. A large amount of effluent generated by the purification can reach 0.2 


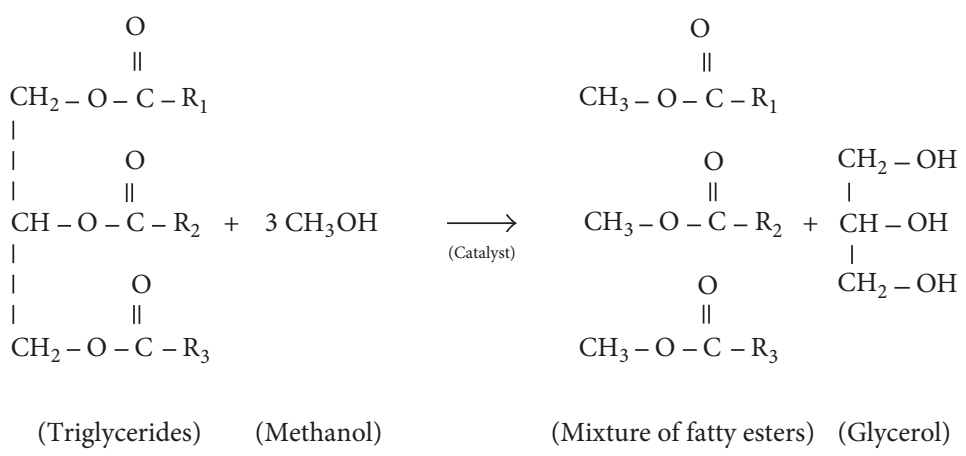

FIGURE 1: Transesterification reaction equation.

tons per ton of biodiesel produced [21]. This contaminated water usually requires treatment before being discharged. In addition, after removal of glycerol, additional purification steps are necessary in order to exploit it. Moreover, when the raw material contains a high content of water and free fatty acids, as is the case for waste frying oils, the yield and quality of biodiesel decrease because of the orientation of the reaction to other adverse reactions [21]. To avoid these drawbacks researchers and business people looking for different biodiesel production methods found that using the enzymatic route offers considerable advantages $[7,8,22]$ including the very high purity of the final product [23]. Lipases are a group of enzymes which have the capacity to catalyze the hydrolysis of ester bonds they have been defined as glycerol ester hydrolases (E.C.3.1.1.3) [24]. These enzymes catalyze not only hydrolysis reactions but also various synthetic reactions including transesterification [24]. Several researchers have reported that the commercially available Candida antarctica lipase (Novozyme 435) was the most effective lipase between any of the lipases tested for transesterification reaction [17, 23, 25]. The high cost of the lipase enzyme seems to be the obstacle for commercially feasible enzymatic production of biodiesel fuels. In order to reduce the cost, Ban et al. (2002) [26] created an alternative technique that involves the direct usage of microorganisms as whole-cell biocatalysts. Filamentous fungi expressing the lipase on the surface have raised the most robust whole-cell biocatalyst [17, 27].

This paper will focus on the waste recovering into biodiesel by different transesterification processes. It provides a comparison of the obtained yields of fatty acid methyl esters and the physical properties of each produced biodiesel.

\section{Materials and Methods}

2.1. Raw Material Used for Experiments. For the production of biodiesel we have chosen to use two organic wastes which are frying oils (WFO) and beef fats (WBF). WBF was collected from different butchers. It was heated by high temperatures to be liquefied. WFO were collected from a restaurant. Before processing, these two materials were filtered to remove solid residues.

2.2. Equipment Used for Physicochemical Properties Characterization. In order to measure the different physical and chemical properties of the raw material stock and the final biodiesel product, a Herzog HVM 472 viscometer for the viscosity measurement and a $684 \mathrm{KF}$ coulometer Metrohm for water content measurement were used.

2.3. GC-MS Analysis Conditions. Fatty acid methyl ester (FAME) content in produced biodiesel was investigated by gas chromatography-mass spectrometry (GC-MS) analysis using an Agilent GC system 7890A coupled with a mass spectrometer Agilent 5975C inert XL MSD with electron impact ionization $(70 \mathrm{eV})$. An HP-5MS capillary column (30 $\mathrm{m} \times 0.25 \mathrm{~mm}$ coated with $5 \%$ phenyl methyl silicone, $95 \%$ dimethylpolysiloxane, $0.25 \mu \mathrm{m}$ film thickness) was used. The FAME composition in the biodiesel product was determined using an analysis by GC-MS. After each transesterification reaction, $200 \mu \mathrm{L}$ samples were taken from the reaction medium and centrifuged at 13,000 rpm for $15 \mathrm{~min} .100 \mu \mathrm{L}$ of the supernatant was mixed with $2 \mathrm{~mL}$ of hexane, and a small amount of sodium sulfate was added to dehydrate the mixture [17]. $1 \mu \mathrm{L}$ volume of the treated sample was then injected into the column.

2.4. Alkaline-Catalyzed Transesterification. Many basic catalysts are used for the transesterification reaction. Potassium hydroxide $\mathrm{KOH}$ gives the best yield of FAME [28]. The transesterification reaction was carried out in glass bottles of $250 \mathrm{~mL}$. It was performed in duplicate for each type of fat. The amounts of reactants and the reaction mixture components have been optimized by Al-Hamamre and Yamin (2013) [4]. First, the bottle was filled with $100 \mathrm{~g}$ of WFO and WBF separately and then heated at $50^{\circ} \mathrm{C} .1 \mathrm{~g}$ of $\mathrm{KOH}$ was dissolved in $44 \mathrm{~mL}$ of methanol and heated to the temperature needed for the experiment. The solution was added to the bottle and the reaction mixture was stirred vigorously for one hour. After the reaction step, the samples were immediately transferred to separating funnel. Two layers were distinguished: the ester layer (upper layer) and glycerol layer (bottom layer). After removing the glycerol, biodiesel is not considered a pure product. Then successive washing steps with hot water were carried out to remove traces of soap formed optionally. Then a few drops of acetic acid were added to neutralize the $\mathrm{KOH}$ unreacted during transesterification.

2.5. Commercial Lipase-Catalyzed Transesterification. The two commercial lipases used in this work are the lipase 


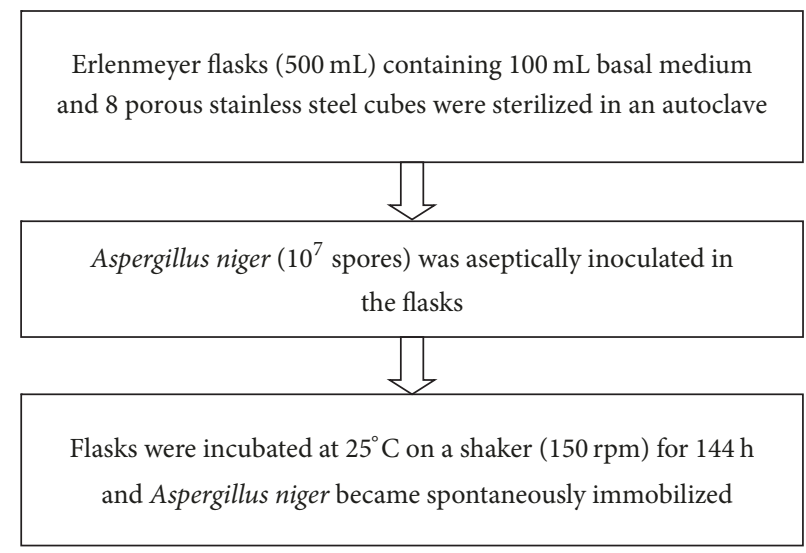

FIGURE 2: Whole-cell biocatalysts preparation.

G "Amano" 50 and Novozyme 435. Indeed, the Novozyme 435 is frequently employed for biodiesel production [20]. It was used for the first time by Nelson et al. in 1996 $[29,30]$. This enzyme is a lipase from Candida antarctica immobilized on acrylic resin (Sigma Aldrich). The second commercial enzyme, the lipase G "Amano" 50, from Penicillium camemberti (Sigma Aldrich), was chosen as a free enzyme. The enzymatic activity of both enzymes was initially characterized and estimated at $7-8 \mathrm{UI} / \mathrm{mg}$ for both of them. The production of FAME catalyzed by both enzymes mentioned above was applied in glass bottles of $500 \mathrm{~mL}$. It was performed in duplicate for each type of fat. For $100 \mathrm{~g}$ of raw material, $4 \mathrm{~g}$ of methanol was necessary to complete the reaction. The mixture was heated up to $40^{\circ} \mathrm{C}$ so that we can add the lipase. Agitation of $150 \mathrm{rpm}$ was maintained for 48 hours. The action of enzymes may be inhibited by the amount of methanol. For the addition of methanol we used the technique adopted by Ban et al. (2002) [26] and optimized by Hashemizadeh et al. (2011) [17]. The methanol was added stepwise to the reaction mixtures three times at 0 , 4 , and $18 \mathrm{~h}$. After $48 \mathrm{~h}$ of reaction, the lipase is separated from the medium by filtration. The mixture obtained is decanted several times to finally obtain a product free of glycerol. Novozyme 435 separated from the reaction medium was reused for the synthesis of biodiesel. In contrast, this is not the case for the lipase G. The immobilized lipase was washed with hexane to eliminate all traces of methanol or glycerol [6]. Then it went through two successive production cycles.

2.6. Whole-Cell Lipase-Catalyzed Transesterification. For this part, Aspergillus niger was investigated for biodiesel production. Indeed, this strain has a high capacity in the production of the lipase. And these dried Aspergillus niger cells could be efficiently immobilized within porous stainless steel cubes to catalyze the transesterification of WFO and WBF [27]. Aspergillus niger cells were grown in a basal medium which was prepared in $1 \mathrm{~L}$ distilled water and contained $35 \mathrm{~g}$ peptone, $35 \mathrm{~g}$ tryptone $1.0 \mathrm{~g} \mathrm{NaNO}_{3}, 1.0 \mathrm{~g} \mathrm{KH}_{2} \mathrm{PO}_{4}, 0.5 \mathrm{~g} \mathrm{MgSO}_{4}$ $7 \mathrm{H}_{2} \mathrm{O}$, and $30 \mathrm{~g}$ olive oil. The whole-cell biocatalysts were prepared as described in Figure 2. During fungi cultivation, and at regular $24 \mathrm{~h}$ intervals, samples were withdrawn and assayed for lipase activity. It was measured according to the method of Lopes et al. (2011) [31], using the quantitative assay by titration of the liberated fatty acids after contact between enzymes and the substrate (triglyceride emulsion). Liberated fatty acids were immediately titrated by $\mathrm{NaOH}$ solution $(0.05 \mathrm{M})$. The lipase activity was calculated as follows:

$$
\begin{aligned}
\operatorname{activity}(\mu \mathrm{mol} / \mathrm{mL} / \mathrm{min})= & \frac{\text { required volume of } \mathrm{NaOH}(\mathrm{L}) \times \mathrm{NaOH} \text { concentration }(\mathrm{mol} / \mathrm{L})}{\text { incubation time }(\mathrm{min})} \\
& \times \text { volume of the lipase extract }(\mathrm{L}) .
\end{aligned}
$$

After the culture, and when a maximum lipase activity is detected according to the results of a first culture, stabilization of the whole-cell biocatalysts was developed according to the method of Ban et al. (2002) [26]. The steps are shown in Figure 3. Once the biocatalyst is stabilized, biodiesel production can take place. The transesterification reaction takes 48 hours in glass bottles of 500. Oil or fat (100 g) was mixed with methanol. The introduced amount of biocatalyst, previously prepared, is $10 \%(\mathrm{w} / \mathrm{w})$ biocatalyst/raw materials. $4 \mathrm{~g}$ of methanol was added stepwise to the reaction mixtures three times at 0,4 , and $18 \mathrm{~h}[17,26,27,32]$. After 48 hours of reaction, we filtered the mixture to remove the stainless steel cubes containing the biocatalyst, and then we left a few hours of rest in the middle to separate the glycerol formed. Since 
TABLE 1: Determination of acid value, water content, and viscosity of raw WFO and WBF.

\begin{tabular}{lccc}
\hline Raw material & Acid value $(\mathrm{mgKOH} /$ goil $)$ & Water content $(\mathrm{mg} / \mathrm{Kg})$ & Viscosity $\left(\mathrm{mm}^{2} / \mathrm{s}\right)$ \\
\hline Waste frying oils & 1.51 & 1577.50 & 32.888 \\
Waste beef fats & 0.86 & 1433.50 & 47.07 \\
\hline
\end{tabular}

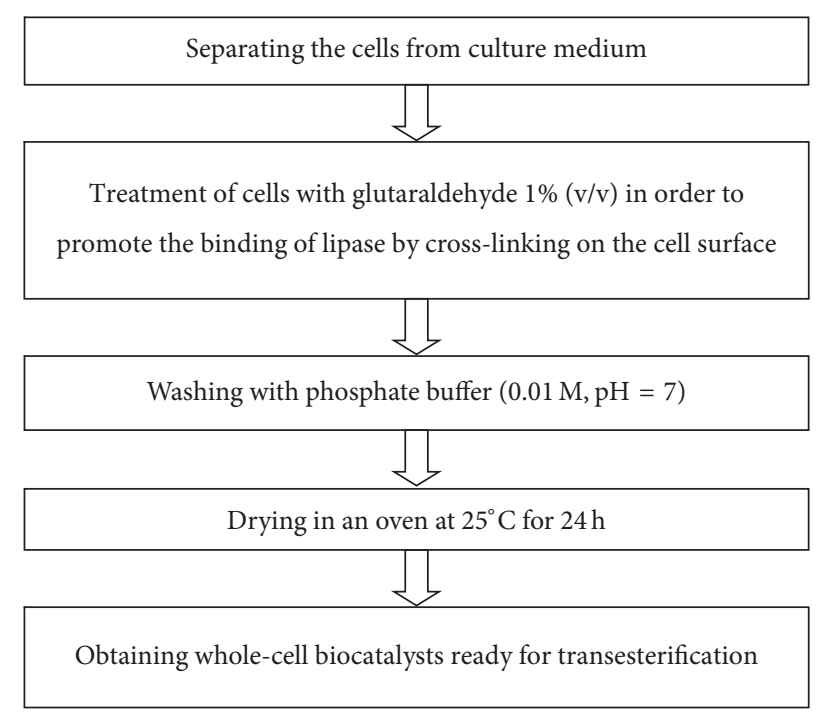

FIGURE 3: Whole-cell biocatalysts stabilization.

we performed the immobilization of biocatalysts, we tested their ability to catalyze two additional cycles of biodiesel production.

2.7. Biodiesel Purification. Subsequent processing steps are necessary to obtain a pure biodiesel. They were performed for all the products from various conversion processes and from different raw materials. They are presented in Figure 4.

2.8. Statistical Analysis. Results are reported as the mean \pm standard deviation. Analysis of variance was performed by ANOVA procedures (SPSS 14.0 for Windows). Significant differences between means were determined by Tukey's post hoc tests. Difference is not that significant $(p<0.05)$.

\section{Results and Discussion}

3.1. Raw Material Properties Determination. The first necessary step was to determine some properties of the two organic wastes (WFO and WBF). The results are compiled in Table 1. As shown in this table, the acid values expose the low amount of free fatty acids (FFA) in both types of oils. Water content of the two oils is considered of significant high amount indicating its nonsuitability for use in biodiesel engine. WFO and WBF have also significant high viscosities. Both oils' physicochemical properties indicate the limitation to the use as fuel in diesel engines due to the troubles that may be caused in the fuel spray atomization and the fuel injectors functioning.

\subsection{Physicochemical Properties of Biodiesel before and after Chemical and Biological Transesterification}

3.2.1. Alkaline-Catalyzed Transesterification. To investigate the effect of alkaline catalysts on the transesterification of WFO and WBF, potassium hydroxide $(\mathrm{KOH})$ was used.

(i) Biodiesel Viscosity. The viscosities of WFO and WBF after alkaline transesterification were determined on the basis of the European specific standard method (EN14214). Herzog HVM 472 equipment was used for viscosity assessment. Figure 5 shows that compared to the high noticed viscosity values of the raw material, a significant decline estimated at around $88 \%$ for both oils viscosities was observed. This decrease is due to the transesterification reaction as described by Fukuda et al. (2001) [12]. This is mainly due to the molecular structure modification. In fact, the triglycerides initially are presented in a polymer structure. After the transesterification reaction, we assist to a fractionation of this complex into simpler macromolecule [13]. In fact, the triglycerides are converted into alkyl esters.

Thus, the produced biodiesel has much lower viscosity, which makes it more appropriate for replacing petroleum diesel in diesel engines. The main reason why alkyl ester is used as fuel and not the crude oil is the reduction in viscosity. The kinematic viscosity is used to monitor biodiesel quality during storage as it is in a continuous increase in parallel with its quality decrease [33]. This property can also be used for the profile of fatty acids choice in the raw material used 


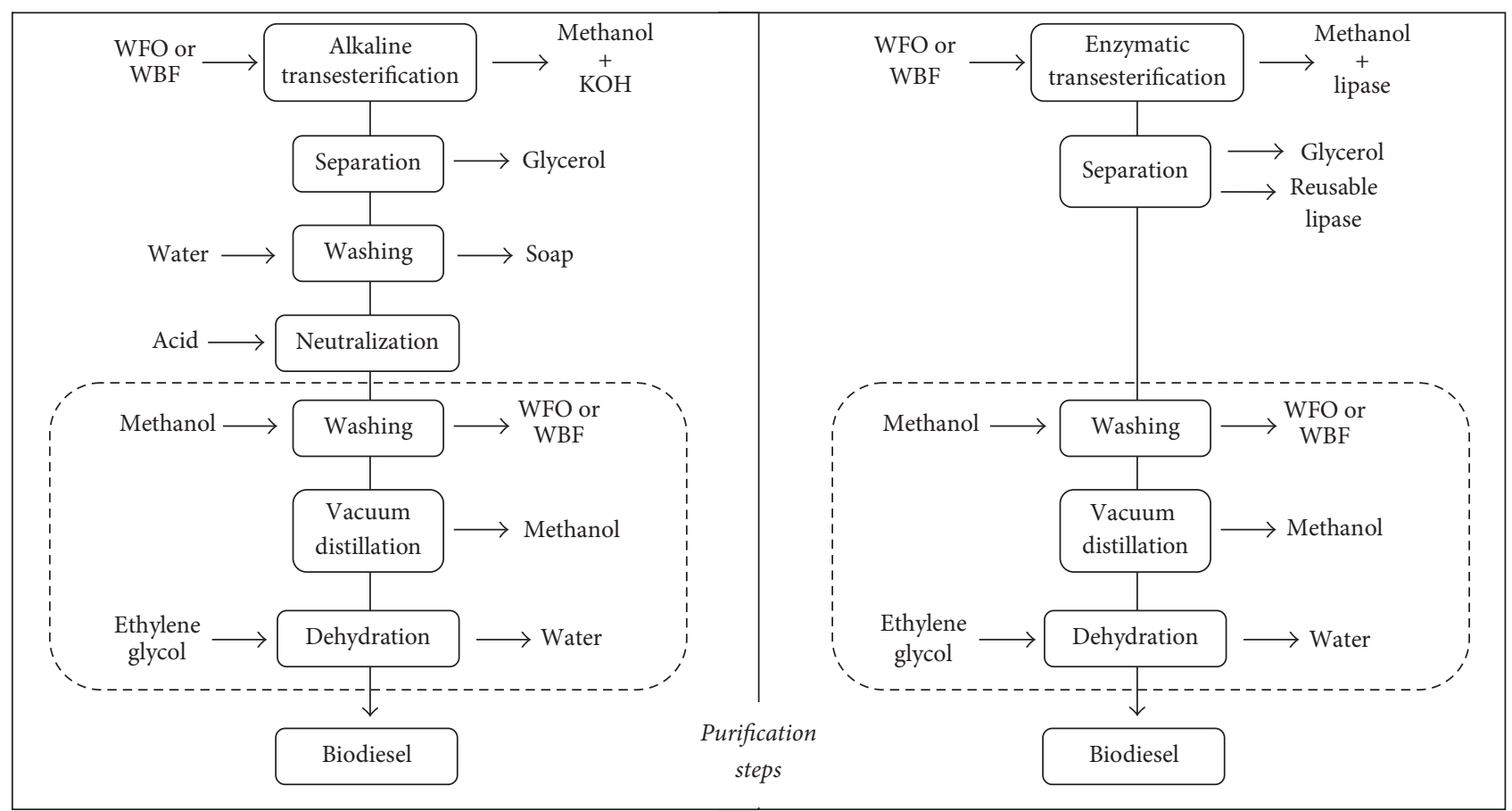

FIGURE 4: Simplified process flow chart of both alkaline and enzymatic catalyzed biodiesel production.
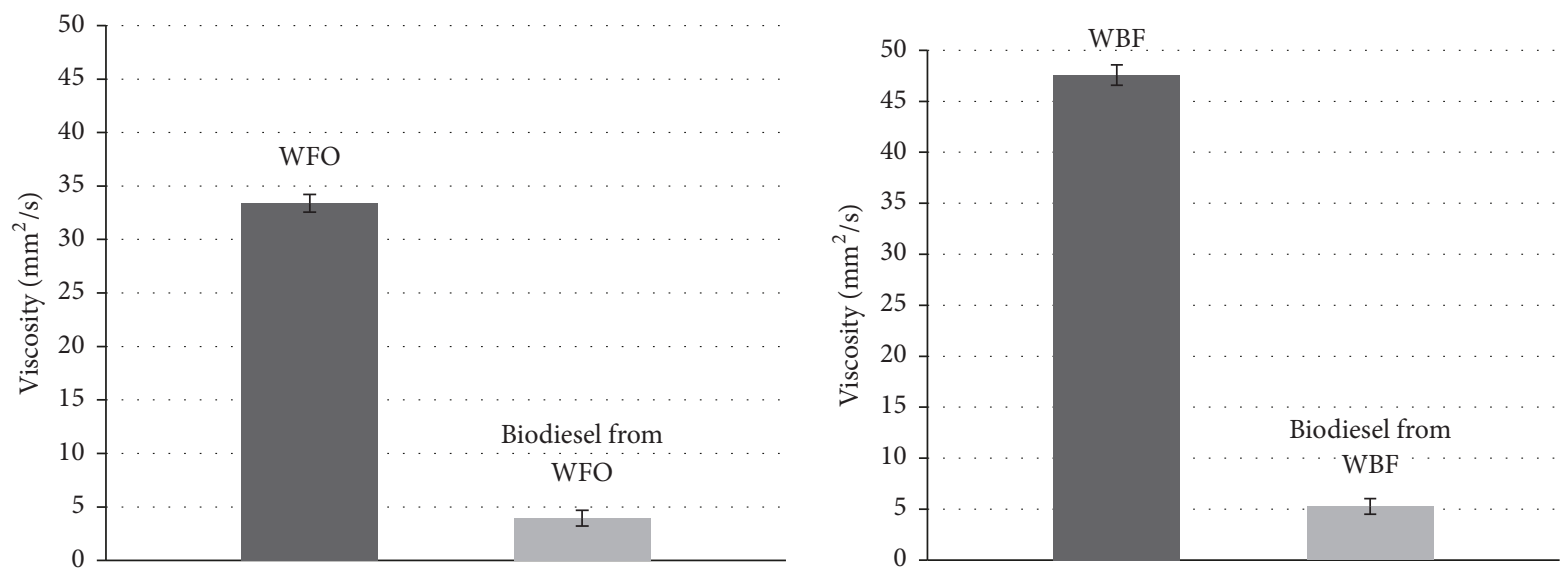

FIGURE 5: Viscosity of biodiesel before and after alkaline transesterification. WFO: waste frying oils, WBF: waste beef fats. Data are means \pm $\mathrm{SD}$ of three independent experiments.

for the production of the biofuel. An increase in the length of the chain and/or in the saturation degree proportionally increases the viscosity [33]. Factors such as the position and the configuration of the double bonds can also have an influence on the viscosity. For example, a cis double bound presents a smaller viscosity than a trans one [33]. (ii) Biodiesel Acid Value. Quality control of biodiesel fuel (BDF) on acid value (AV) is also important since the number increase is correlated to fuel deterioration as well as nonconformity of production process. Thus, in the current study the biodiesel was also determined according to the following equation:

$$
\text { acid value }=\frac{\text { molar mass of } \mathrm{KOH} \times \mathrm{KOH} \text { concentration } \times \text { volume of required solution }(\text { ethanol }+\mathrm{KOH})}{\text { mass of the test sample }} .
$$


TABLE 2: Determination of acid value, water content, and viscosity of biodiesel issued from WFO and WBF transesterification through the biological process.

\begin{tabular}{|c|c|c|c|c|c|}
\hline Raw material & Catalyst & $\begin{array}{c}\text { Acid value } \\
(\mathrm{mgKOH} / \text { goil })\end{array}$ & $\begin{array}{c}\text { Acid value EN14214 } \\
\text { standard } \\
\text { mgKOH/goil }\end{array}$ & Viscosity $\left(\mathrm{mm}^{2} / \mathrm{s}\right)$ & $\begin{array}{c}\text { Viscosity EN14214 } \\
\text { standard } \mathrm{mm}^{2} / \mathrm{s}\end{array}$ \\
\hline \multirow{2}{*}{ Waste frying oils } & Commercial lipase & 5.749 & \multirow{4}{*}{0.5} & 5.829 & \\
\hline & Whole-cell & 2.240 & & 6.115 & 3.5 to 5 \\
\hline \multirow{2}{*}{ Waste beef fats } & Commercial lipase & 1.226 & & 6.445 & S \\
\hline & Whole-cell & 2.572 & & 9.999 & \\
\hline
\end{tabular}

The acid value (AV) should be one of the first assessed items in analysis, since this value can reflect the biodiesel process production efficiency. If the AV is high (superior to $2 \mathrm{mg}$ of $\mathrm{KOH}$ per gram of sample), it is possible to assume that some free fatty acids (FFA) remain in the biodiesel. It was reported that the acid wash applied after the transesterification aiming to the removal the alkaline catalyst in order to avoid soap formation can be responsible for high acid numbers. An increase in the AV can cause deposits in the motor and corrosion problems [33]. The acid value of the diesel samples, estimated at 0.562 and 0.554 , respectively for WFO and WBF, are in accordance with the EN14214 standard established at $0.50 \mathrm{mg} \mathrm{KOH} / \mathrm{g}$. The acid value is a measure of the fatty acid level in the biodiesel and depends on two main parameters: the free fatty acid content in the oils and the transesterification process. The acid values were within specifications indicating the satisfying quality of the produced biodiesel.

3.2.2. Commercial Lipase and Whole-Cell-Catalyzed Transesterification. The acid value and the viscosity were also investigated in the case of the biodiesel obtained through the biological process (enzymatic and whole-cell-catalyzed transesterification). After the first assays, the selected enzyme for the commercial lipase reactions was Novozyme 435. In fact, the preliminary results obtained with the lipase $G$ "Amano" 50 showed variability in the obtained values. This could be due to the enhanced stability of the immobilized enzyme. The obtained results are presented in Table 2. It is to be noticed that the estimated acid value and viscosity of the biodiesel obtained by the two biological adopted processes were not satisfying as the values are not included in the range recommended by the EN14214 standard. This observation indicates that the biological process needs some experimental condition adjustments probably in the reaction time and/or the catalyst volume.

3.3. GC-MS Approximative Quantification of FAMEs in Biodiesel Produced by Both Chemical and Biological Transesterification. The chemical structure of FAMEs consists of a nonpolar long chain of hydrocarbon coupled to a methyl ester group. Biodiesel based fatty acid methyl was investigated quantitatively by gas chromatography-tandem mass spectrometry. The yield of FAMEs was estimated using the equation previously reported by Omar and Amin (2011) [34]:

$$
\text { FAMEs yield }(\%)=\frac{\% \text { FAMEs area from GC-MS } \times \text { weight of biodiesel product }}{\text { weight of the raw material sample }} .
$$

As shown in Figure 6, a high number of FAMEs were noted for biodiesel produced by both processes. In fact we have observed $94 \%$ for biological transesterification FAMEs yield slightly higher than chemical transesterification, for which we have noticed $73 \%$ of FAMEs yield. The difference is not that significant but may be due to the reaction specificity of enzymatic and cell reactions. Moreover, we can deduce from Figure 6 that a very slight difference is observed comparing the enzymatic and whole-cell process. The use of the lipase as a free enzyme or inside the whole-cell influences the transesterification rate.

3.4. GC-MS Qualitative Characterization of Biodiesel Produced by Both Chemical and Biological Transesterification. The GC-MS qualitative biodiesel characterization allowed us to identify the biodiesel composition. As an example, we chose to represent the results obtained for the biodiesel obtained by immobilized enzyme transesterification of frying oil (Figure 7). As shown in Figure 7, six main compounds were detected. Those compounds' names and retention times (RT) are 1,2-benzenedicarboxylic acid, dibutyl ester at $5.76 \mathrm{~min}$, hexadecanoic acid, methyl ester at $6.374 \mathrm{~min}$, hexadecanoic acid, 15-methyl-, methyl ester at $7.908 \mathrm{~min}$, 9,12-octadecadienoic acid (Z,Z)-methyl ester at $9.141 \mathrm{~min}, 8$ octadecenoic acid, methyl ester at $9.238 \mathrm{~min}$, and methyl stearate at $9.688 \mathrm{~min}$. It is to be noticed that octadecadienoic acid (Z,Z)-methyl as well as 8-octadecenoic acid, methyl ester had the greatest amount in this biodiesel with respectively an area of $41.066 \%$ and $38.077 \%$. Those two FAMEs are monounsaturated fatty acids. Indeed, the fact that the unsaturated fatty acids are predominant in composition of this biodiesel is advantageous as the saturated fatty acids present a tendency to crystallize at low temperatures, which can limit the use of this fuel in areas of a cold climate [33]. The biodiesels obtained 


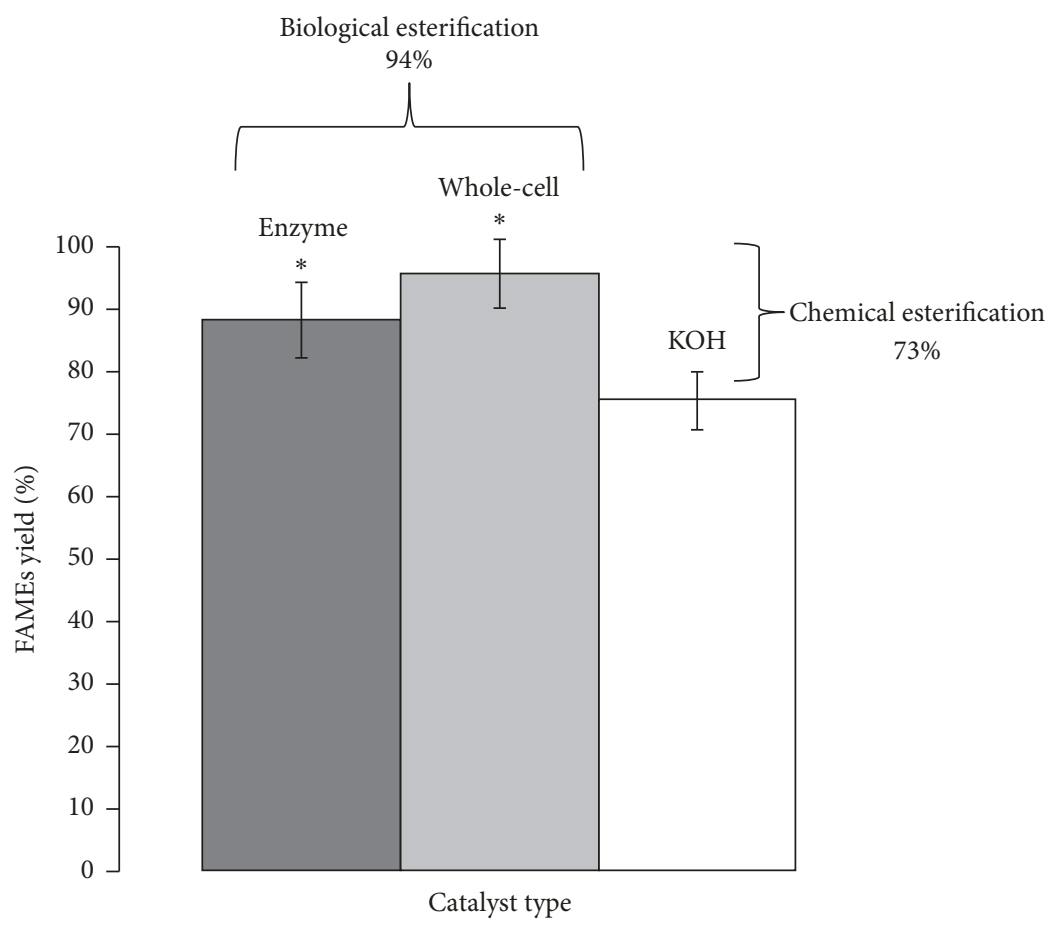

FIGURE 6: FAMEs yield estimated for both chemical and biological transesterification. Data are means \pm SD of three independent experiments. ${ }^{*}$ Difference is not that significant by the Tukey's post hoc tests $(p<0.05)$.

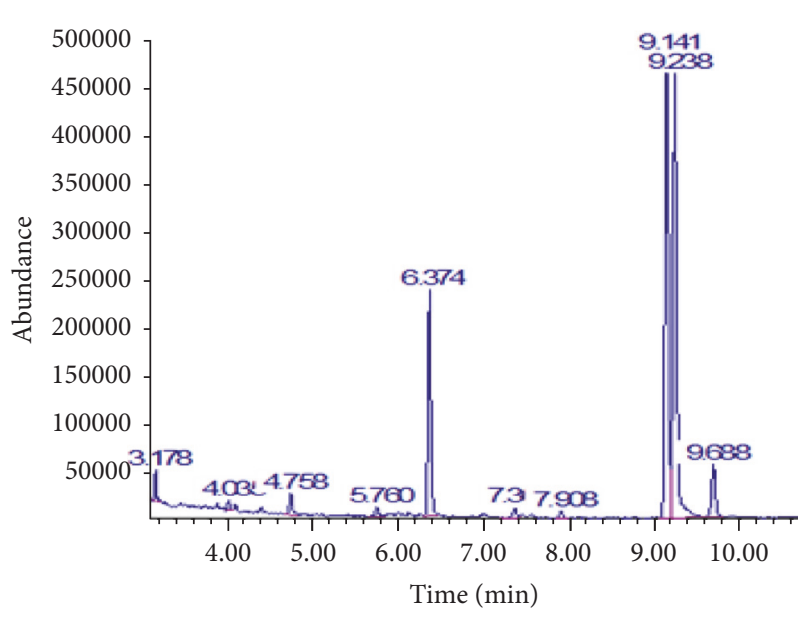

FIGURE 7: Chromatograms of biodiesel obtained by immobilized enzyme transesterification of frying oil.

from WBF using the same enzyme were different from those obtained from the WFO as we obtained in that case 15 FAMEs instead of 6 FAMEs. However we noticed that once again the major fatty acids were the 9,12-octadecadienoic acid (Z,Z)-methyl ester (at $9.141 \mathrm{~min}$ ) and the 8-octadecenoic acid, methyl ester (at $9.238 \mathrm{~min}$ ) with an area of 41.066 and 38.077, respectively. The same tendency was observed for the chemical and whole-cell transesterification with a very varying fatty acid number production but a highest amount of octadecenoic acid, methyl ester isomers. Another important observation was made. For the whole-cell transesterification

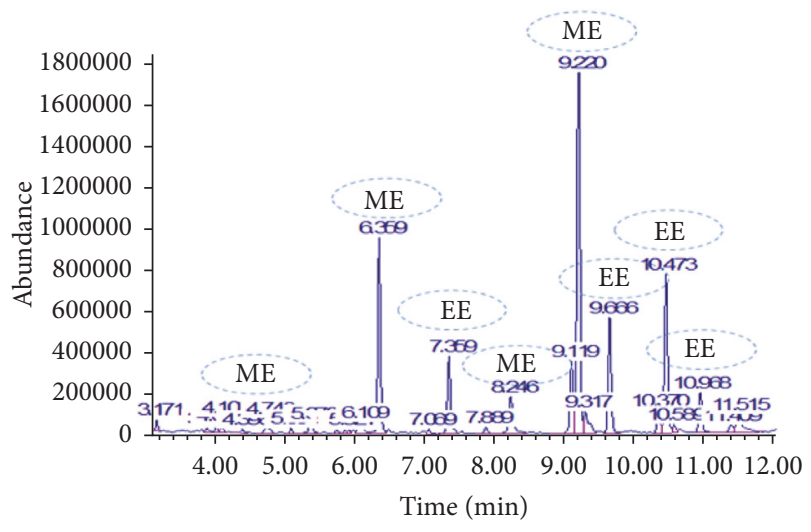

FIGURE 8: Chromatograms of biodiesel obtained by whole-cell transesterification of beef fats. EE: ethyl ester, ME: methyl ester.

process, the GC-MS qualitative biodiesel characterization for both raw material WFO and WBF highlighted that the formed biodiesel was a mixture of alkyl (methyl or ethyl) esters of fatty acids (Figure 8, Table 3). For the alkaline and enzymatic processes, only methyl esters were observed. This result may be explained by the metabolic pathway used by the fungi that implicate several and complex reaction via its enzymatic consortium that may lead to the observed composition diversity in the biodiesel.

\section{Conclusion}

The objective of this study was, in a first step, to investigate two different approaches for biodiesel production by 
TABLE 3: Quantitative composition of the FAMEs of biodiesel formed by whole-cell transesterification process.

\begin{tabular}{lccc}
\hline Peak number $^{*}$ & Ret time $(\mathrm{min})$ & \% Area & Composition \\
\hline 4 & & Waste of beef fats & Hexadecanoic acid, methyl ester \\
6 & 7.39 & 14.70 & Hexadecanoic acid, ethyl ester \\
8 & 7.35 & 6.17 & Hexadecanoic acid, methyl ester \\
9 & 9.24 & 4.28 & 9,12-Octadecadienoic acid (Z,Z)-methyl ester \\
10 & 9.11 & 6.12 & 9-Octadecenoic acid, methyl ester (E) \\
11 & 9.22 & 32.84 & 9-Octadecenoic acid, methyl ester (E) \\
12 & 9.31 & 2.83 & Methyl stearate \\
14 & 9.66 & 9.55 & Ethyl oleate \\
15 & 10.47 & 13.88 & Octadecanoic acid, ethyl ester \\
\hline & 10.96 & 3.70 & Methyl tetradecanoate \\
1 & & Waste of frying oil & Methyl hexadec-9-enoate \\
3 & 4.10 & 2.26 & Hexadecanoic acid, methyl ester \\
4 & 6.11 & 2.53 & Heptadecanoic acid, methyl ester \\
7 & 6.36 & 20.66 & 9,12-Octadecadienoic acid (Z,Z)-methyl ester \\
9 & 7.89 & 3.46 & 9-Octadecenoic acid, methyl ester \\
11 & 9.12 & 4.53 & 10-Octadecenoic acid, methyl ester \\
12 & 9.23 & 35.73 & Octadecanoic acid, methyl ester \\
\hline
\end{tabular}

${ }^{*}$ A total of 16 compounds; only the compounds for which the area $>2 \%$ are presented.

exploiting the frying oil and beef fat as raw material. In a second step, we were interested to compare biodiesel obtained in terms of esters content and fuel properties. Each type of catalysis has its strengths and weaknesses. In fact, all experimental findings show that the chemical method gave the product with the best physicochemical property. The enzymatic one was found more effective for obtaining important ester content.

The chemical method shows many drawbacks, namely, the complexity of downstream processing steps of the product, generating a large amount of contaminated water, and poor performance noted by comparing it with the biological method. However, the biological method offers a very promising route to environmentally acceptable production. It is also important to highlight that one of the advantages of the chemical esterification, compared to the biological one, is the time needed to achieve a satisfying yield. In fact, enzyme catalyzed reactions are more time consuming due to the slower reaction rate. Nevertheless, the enzyme approach is still preferably chosen due the other mentioned advantages. Thus, it would be interesting to optimize the enzymatic pathway of production of biodiesel to obtain a better property of biodiesel, meeting the requirements of EN 14214.

\section{Abbreviations}

AV: $\quad$ Acid value

BDF: Biodiesel fuel

FAME: Fatty acid methyl ester

FFA: $\quad$ Free fatty acids

GC-MS: Gas chromatography-mass spectrometry
RT: Retention time

WBF: Wastes of beef fats

WFO: Wastes of frying oils.

\section{Conflicts of Interest}

The authors declare that they have no conflicts of interest.

\section{Acknowledgments}

This study was cofunded by the Tunisian Ministry of Higher Education, Scientific Research. The authors would like to gratefully acknowledge Ms. Ichrak Ben Hariz from the STIR industry for the technical support. The authors would like also to thank Dr. Ines Ben Rejab from the INSAT for her assistance with the enzymatic experiments and for providing fruitful help and guidance.

\section{References}

[1] E. M. Shahid and Y. Jamal, "Production of biodiesel: a technical review," Renewable \& Sustainable Energy Reviews, vol. 15, no. 9, pp. 4732-4745, 2011.

[2] A. Demirbas, "Progress and recent trends in biodiesel fuels," Energy Conversion and Management, vol. 50, no. 1, pp. 14-34, 2009.

[3] Z. Yaakob, M. Mohammad, M. Alherbawi, Z. Alam, and K. Sopian, "Overview of the production of biodiesel from Waste cooking oil," Renewable \& Sustainable Energy Reviews, vol. 18, pp. 184-193, 2013.

[4] Z. Al-Hamamre and J. Yamin, "Parametric study of the alkali catalyzed transesterification of waste frying oil for Biodiesel 
production," Energy Conversion and Management, vol. 79, pp. 246-254, 2013.

[5] A. Cunha, V. Feddern, M. C. De Prá, M. M. Higarashi, P. G. De Abreu, and A. Coldebella, "Synthesis and characterization of ethylic biodiesel from animal fat wastes," Fuel, vol. 105, pp. 228-234, 2013.

[6] C.-Y. Yu, L.-Y. Huang, I.-C. Kuan, and S.-L. Lee, "Optimized production of biodiesel from waste cooking oil by lipase immobilized on magnetic nanoparticles," International Journal of Molecular Sciences, vol. 14, no. 12, pp. 24074-24086, 2013.

[7] A. E. Ghaly, D. Dave, M. S. Brooks, and S. Budge, "Production of biodiesel by enzymatic transesterification: Review," American Journal of Biochemistry and Biotechnology, vol. 6, no. 2, pp. 5476, 2010.

[8] Y. Chen, B. Xiao, J. Chang, Y. Fu, P. Lv, and X. Wang, "Synthesis of biodiesel from waste cooking oil using immobilized lipase in fixed bed reactor," Energy Conversion and Management, vol. 50, no. 3, pp. 668-673, 2009.

[9] M. G. Kulkarni and A. K. Dalai, "Waste cooking oil-an economical source for biodiesel: a review," Industrial \& Engineering Chemistry Research, vol. 45, no. 9, pp. 2901-2913, 2006.

[10] http://www.anged.nat.tn/.

[11] M. Chauvin, "La réglementation française sur la valorisation agronomique des déchets organiques-organisation et points principaux," ADEME Bretagne, p. 12, 2004.

[12] H. Fukuda, A. Kondo, and H. Noda, "Biodiesel fuel production by transesterification of oils," Journal of Bioscience and Bioengineering, vol. 92, no. 5, pp. 405-416, 2001.

[13] A. A. Refaat, "Correlation between the chemical structure of biodiesel and its physical properties," International Journal of Environmental Science and Technology, vol. 6, no. 4, pp. 677694, 2009.

[14] F. Ma and M. A. Hanna, "Biodiesel production: a review," Bioresource Technology, vol. 70, no. 1, pp. 1-15, 1999.

[15] Y. Wang, S. Ou, P. Liu, F. Xue, and S. Tang, "Comparison of two different processes to synthesize biodiesel by waste cooking oil," Journal of Molecular Catalysis A: Chemical, vol. 252, no. 1-2, pp. 107-112, 2006.

[16] S. Fernando, P. Karra, R. Hernandez, and S. K. Jha, "Effect of incompletely converted soybean oil on biodiesel quality," Energy, vol. 32, no. 5, pp. 844-851, 2007.

[17] S. N. Hashemizadeh, O. Tavakoli, F. Tabandeh, A. A. Karkhane, and Z. Forghanipour, "A Comparative Study of ImmobilizedWhole Cell and Commercial Lipase as a Biocatalyst for Biodiesel Production from Soybean Oil," in Proceedings of the World Renewable Energy Congress - Sweden, pp. 311-318, Linkoping, Sweden, 8-13 May, 2011.

[18] S. Al-Zuhair, "Production of biodiesel by lipase-catalyzed transesterification of vegetable oils: A kinetics study," Biotechnology Progress, vol. 21, no. 5, pp. 1442-1448, 2005.

[19] W. Du, Y.-Y. Xu, D.-H. Liu, and Z.-B. Li, "Study on acyl migration in immobilized lipozyme TL-catalyzed transesterification of soybean oil for biodiesel production," Journal of Molecular Catalysis B: Enzymatic, vol. 37, no. 1-6, pp. 68-71, 2005.

[20] A. Talebian-Kiakalaieh, N. A. S. Amin, and H. Mazaheri, "A review on novel processes of biodiesel production from waste cooking oil," Applied Energy, vol. 104, pp. 683-710, 2013.

[21] K.-I. Suehara, Y. Kawamoto, E. Fujii, J. Kohda, Y. Nakano, and T. Yano, "Biological treatment of wastewater discharged from biodiesel fuel production plant with alkali-catalyzed transesterification," Journal of Bioscience and Bioengineering, vol. 100, no. 4, pp. 437-442, 2005.
[22] A. Bajaj, P. Lohan, P. N. Jha, and R. Mehrotra, "Biodiesel production through lipase catalyzed transesterification: An overview," Journal of Molecular Catalysis B: Enzymatic, vol. 62, no. 1, pp. 9-14, 2010.

[23] I. Kazanceva, P. d. Makareviciene, and K. Kazancev, "Application of Biotechnological Method to Biodiesel Fuel Production using n-butanol," Environmental Research, Engineering and Management, vol. 56, no. 2, 2011.

[24] D. M. Guimarães Freire, J. S. de Sousa, and E. D. CavalcantiOliveira, "Biotechnological methods to produce biodiesel," Biofuels, pp. 315-337, 2011.

[25] Y. Shimada, Y. Watanabe, T. Samukawa et al., "Conversion of vegetable oil to biodiesel using immobilized Candida antarctica lipase," Journal of the American Oil Chemists' Society, vol. 76, no. 7, pp. 789-793, 1999.

[26] K. Ban, S. Hama, K. Nishizuka et al., "Repeated use of wholecell biocatalysts immobilized within biomass support particles for biodiesel fuel production," Journal of Molecular Catalysis B: Enzymatic, vol. 17, no. 3-5, pp. 157-165, 2002.

[27] M. Xiao, C. Qi, and J. P. Obbard, "Biodiesel production using Aspergillus niger as a whole-cell biocatalyst in a packed-bed reactor," Global Change Biology Bioenergy, vol. 3, no. 4, pp. 293 298, 2011.

[28] A. P. Singh, B. B. He, J. C. Thompson, and J. H. van Gerpen, "Process optimization of biodiesel production using alkaline catalysts," Applied Engineering in Agriculture, vol. 22, no. 4, pp. 597-600, 2006.

[29] L. A. Nelson, T. A. Foglia, and W. N. Marmer, "Lipase-catalyzed production of biodiesel," Journal of the American Oil Chemists' Society, vol. 73, no. 9, pp. 1191-1195, 1996.

[30] M. K. Lam, K. T. Lee, and A. R. Mohamed, "Homogeneous, heterogeneous and enzymatic catalysis for transesterification of high free fatty acid oil (waste cooking oil) to biodiesel: a review," Biotechnology Advances, vol. 28, no. 4, pp. 500-518, 2010.

[31] D. B. Lopes, L. P. Fraga, L. F. Fleuri, and G. A. Macedo, "Lipase and esterase: to what extent can this classification be applied accurately?" Ciência e Tecnologia de Alimentos, vol. 31, no. 3, pp. 603-613, 2011.

[32] M. Xiao, S. Mathew, and J. P. Obbard, "A newly isolated fungal strain used as whole-cell biocatalyst for biodiesel production from palm oil," Global Change Biology Bioenergy, vol. 2, no. 2, pp. 45-51, 2010.

[33] M. S. Aranda Moraes, L. C. Krause, M. E. da Cunha et al., "Tallow biodiesel: Properties evaluation and consumption tests in a diesel engine," ENERGY \& FUELS, vol. 22, no. 3, pp. 19491954, 2008.

[34] W. N. N. W. Omar and N. A. S. Amin, "Biodiesel production from waste cooking oil over alkaline modified zirconia catalyst," Fuel Processing Technology, vol. 92, no. 12, pp. 2397-2405, 2011. 

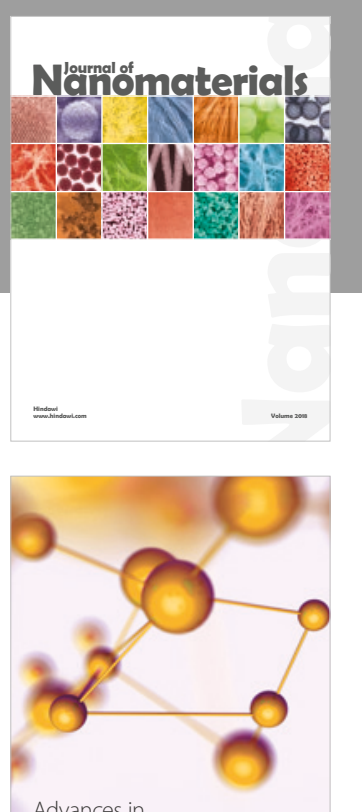

Physical Chemistry
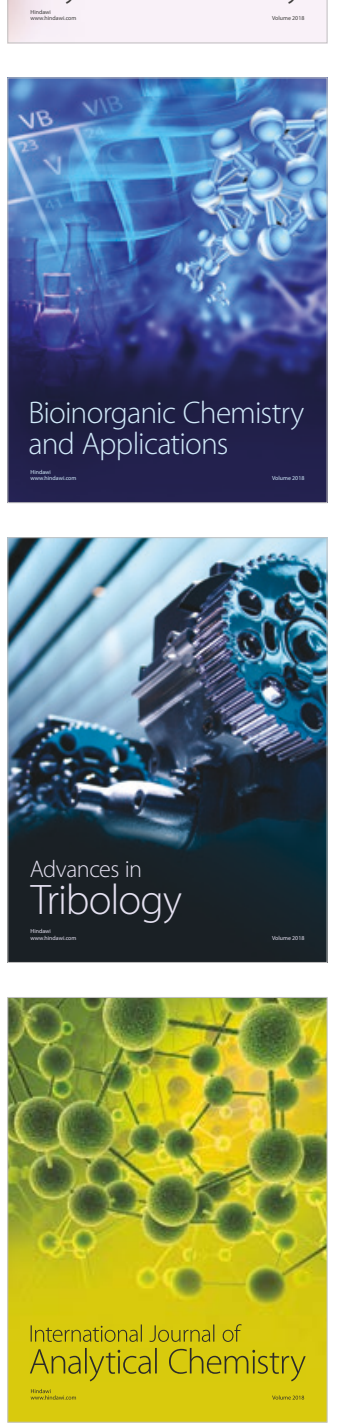

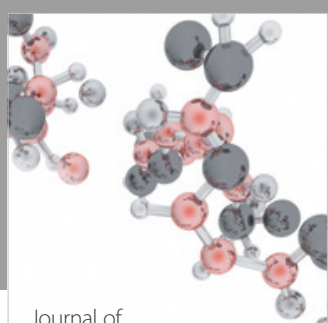

Analytical Methods

in Chemistry

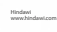

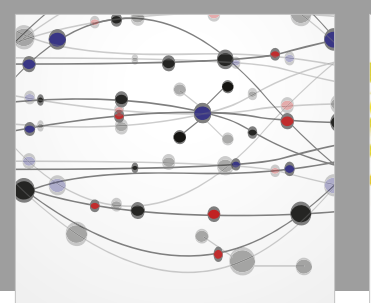

The Scientific World Journal

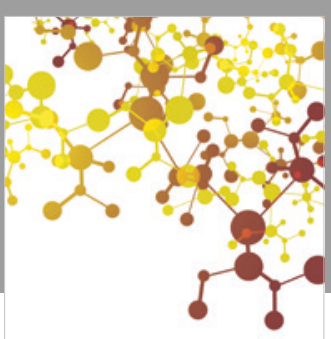

Journal of

Applied Chemistry
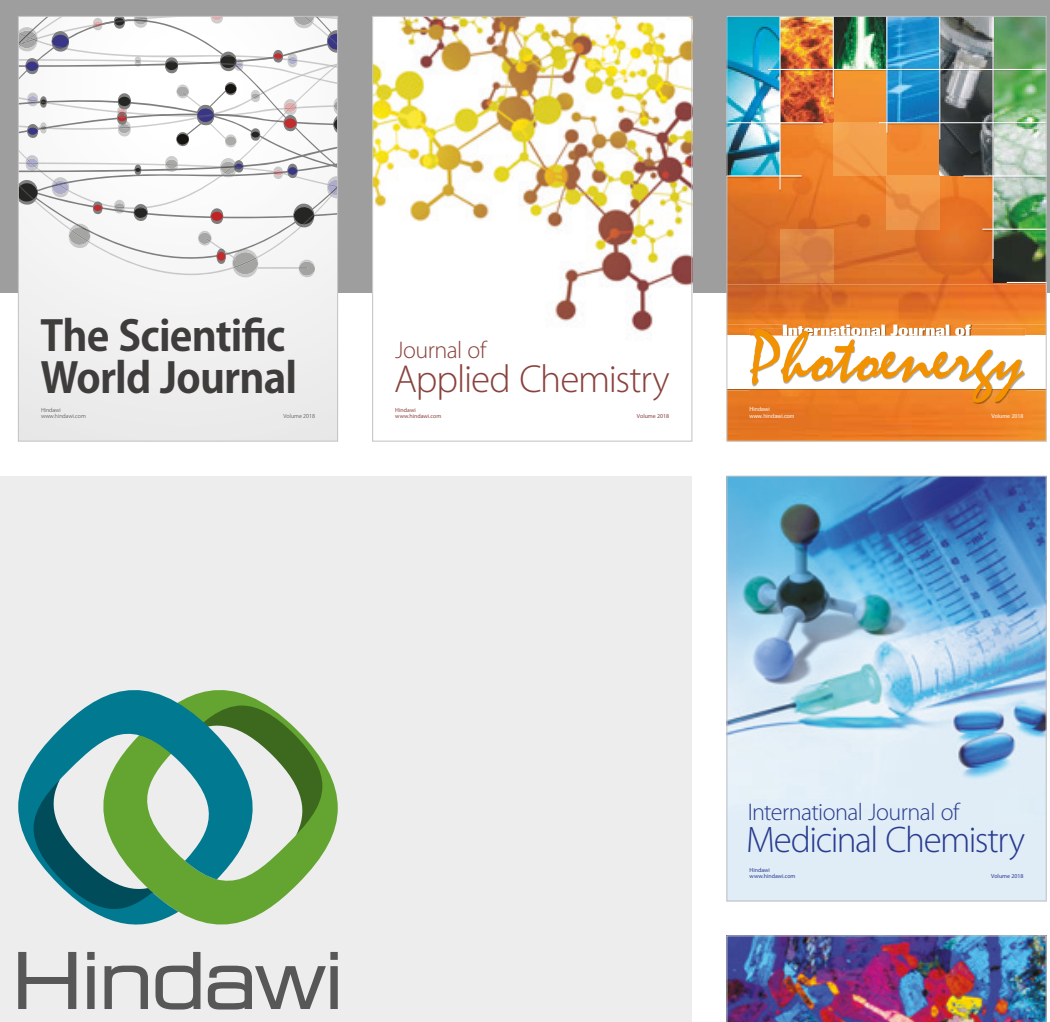

Submit your manuscripts at

www.hindawi.com
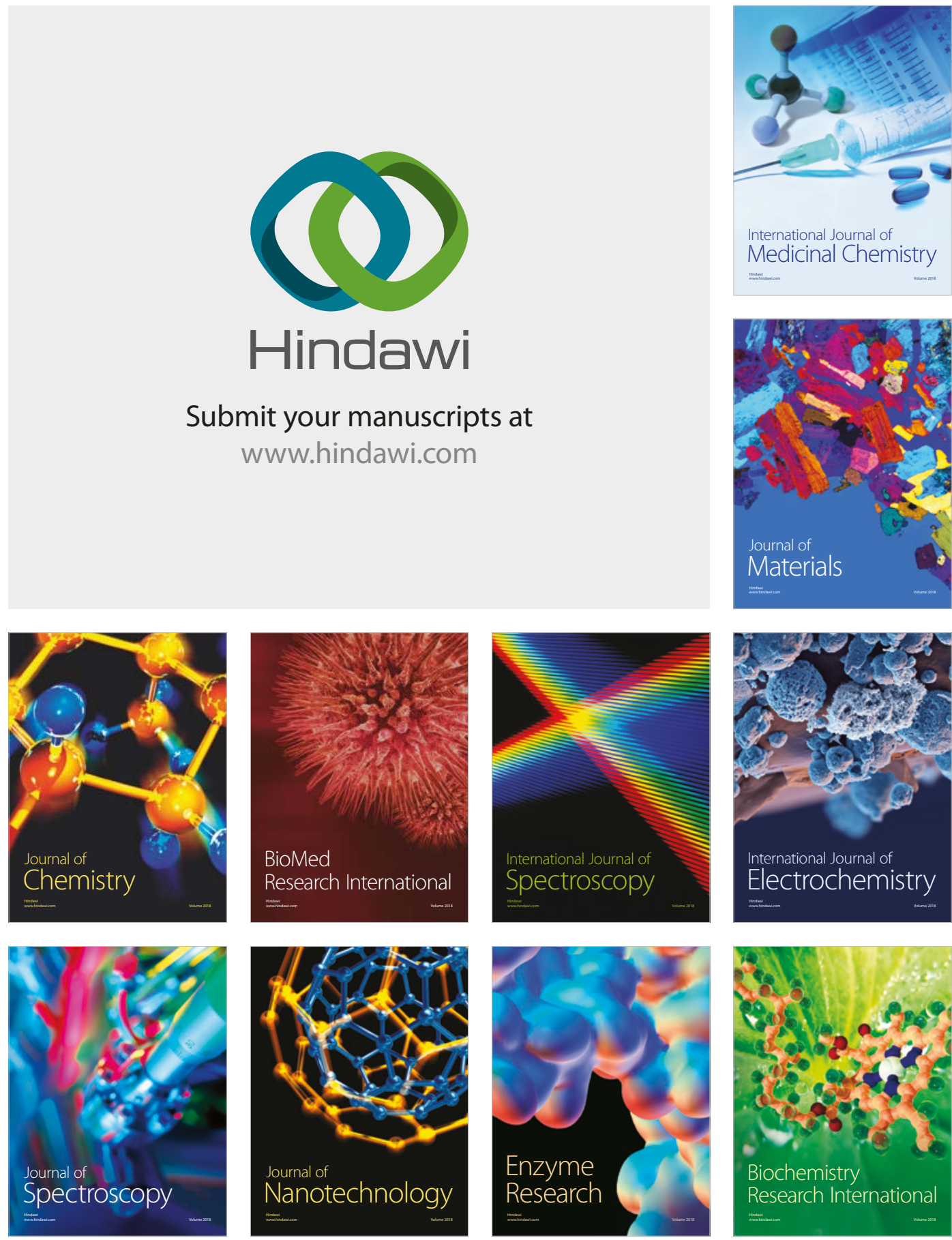
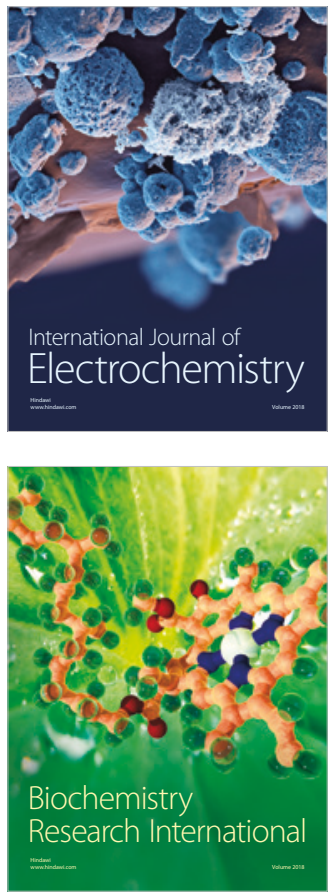